\title{
Optimized Biosurfactant Production by Pseudomonas aeruginosa Strain CGA1 Using Agro-Industrial Waste as Sole Carbon Source
}

\author{
Chikodili G. Anaukwu* ${ }^{\circledR}$, Chioma M. Ogbukagu, Ikechukwu A. Ekwealor \\ Department of Applied Microbiology and Brewing, Nnamdi Azikiwe University, Awka, Nigeria \\ Email: *cg.anaukwu@unizik.edu.ng
}

How to cite this paper: Anaukwu, C.G., Ogbukagu, C.M. and Ekwealor, I.A. (2020) Optimized Biosurfactant Production by Pseudomonas aeruginosa Strain CGA1 Using Agro-Industrial Waste as Sole Carbon Source. Advances in Microbiology, 10, 543-562.

https://doi.org/10.4236/aim.2020.1010040

Received: August 12, 2020

Accepted: October 25, 2020

Published: October 28, 2020

Copyright $\odot 2020$ by author(s) and Scientific Research Publishing Inc. This work is licensed under the Creative Commons Attribution International License (CC BY 4.0).

http://creativecommons.org/licenses/by/4.0/ (c) (i) Open Access

\begin{abstract}
Biosurfactants are biomolecules produced by microorganisms, which possess several advantages over their chemical counterparts. Production can be cost-effective if renewable wastes are utilized as substrates. In this study, optimization of biosurfactant production by Pseudomonas aeruginosa strain CGA1 was carried out using response surface methodology. The conventional "One factor at a time" method of optimization was initially adopted to ascertain the impact of different renewable wastes on biosurfactant production. Four independent variables were tested: carbon and nitrogen concentration, medium volume, and inoculum size. Biosurfactant production was based on the emulsification index measurement. Results indicated that the preferred carbon source by the isolate was sugar cane molasses. A 2.31-fold increase in biosurfactant yield and emulsification index of $96.3 \% \pm 0.75 \%$ under optimized cultural conditions of $20 \mathrm{~g} / \mathrm{L}$ of molasses, $5 \mathrm{~g} / \mathrm{L}$ of sodium nitrate, 1.93 $\mathrm{ml}$ inoculum size and $60 \mathrm{ml}$ medium volume in $250 \mathrm{ml}$ conical flask were obtained. The regression coefficient $\left(\mathrm{R}^{2}\right)$ value of $84.15 \%$ implied adequate fitness of the model. The surface tension of distilled water was reduced from $72.1 \mathrm{mN} / \mathrm{m}$ to $35.0 \pm 0.0 \mathrm{mN} / \mathrm{m}$, and critical micelle concentration was attained at $60 \mathrm{mg} \cdot \mathrm{L}^{-1}$. FTIR and GC-MS analysis indicated that the biosurfactant was a lipopeptide having characteristic lipid and peptide peak values. This study proves that the sole use of agro-industrial wastes for the production of biosurfactant is very efficient, and ensures the economic feasibility of biosurfactant production.
\end{abstract}

\section{Keywords}

Pseudomonas aeruginosa, Optimization, Response Surface Methodology, Biosurfactant, Sugar Cane Molasses, Lipopeptide 


\section{Introduction}

Surface active agents (surfactant) are substances that contain both hydrophilic and hydrophobic groups in their chemical structure. Surfactants produced by microorganisms, usually during their stationary phase of life are referred to as biosurfactants [1]. The industrial need for biosurfactants over synthetic surfactant is constantly growing [2]. They are excellent at the surface and interfacial tension reduction owing to their amphiphilic nature. They have several advantages over the synthetic counterparts which range from eco-friendliness, non-recalcitrancy, degradability, and non-toxicity. They can be easily produced from low-cost renewable resources such as agro-industrial wastes, allow for the evolvement of economical bioprocess [3], and use of recombinant strains for improved production yield [4].

Several bacterial genera have been reported as biosurfactant producers, for example, Acinetobacter, Arthrobacter, Pseudomonas, Halomonas, Bacillus, Rhodococcus, Enterobacter, Serratia [5] [6] [7] [8], and fungal species such as Saccharomyces cerevisiae [9], Fusarium fujikuroi [10], Candida tropicalis [11], Pseudozyma [12], Xylaria regalis [13]. Pseudomonas aeruginosa strains are among the effective producers of biosurfactant [14] [15]. They are known for producing glycolipids and lipopeptides, which have been excellently applied in bioremediation and the biomedical field as antibacterial, antifungal, antiviral and antiadhesives [16] [17] [18]. They have also been used in the preparation of nanoparticles [19] and microemulsions [20].

Agro-industrial wastes from crop residues, animal fats, coffee processing residues, dairy and distillery industries, fruit and food processing industries, and oil processing industries, contain a high amount of carbohydrates and lipids, hence, can be used as rich carbon sources for microbial growth [21]. They have been used as a sole or supplementary carbon source during biosurfactant production.

Optimization of fermentation medium conditions such as carbon and nitrogen concentration, $\mathrm{pH}$, temperature, inoculum size, medium volume, and the incubation period is also one of the strategies for cost-effective biosurfactant production [22]. Response surface methodology (RSM) is one of the many statistical/mathematical tools employed to optimize experimental variables by defining the relationship between variables and the response factors. RSM is effectively used to design experiments, write and analyze multiple regression models and fit the models, analyze the linear and quadratic effect of several experimental variables, and establish the variable conditions for an optimum response [23] [24]. Several studies have been conducted on biosurfactant production by Pseudomonas aeruginosa and the optimization of process parameters using various designs of experiment tools [25] [26]. The present work aimed to optimize biosurfactant production by Pseudomonas aeruginosa strain CGA1 using response surface methodology (RSM), with an agro-industrial waste as the carbon source, and to characterize its chemical structure by Fourier 
transform infrared spectroscopy (FTIR) and gas chromatography-mass spectroscopy (GC-MS).

\section{Material and Methods}

\subsection{Isolation and Identification of the Biosurfactant-Producing Organism}

Pseudomonas aeruginosa strain CGA1 (GenBank accession no. MT318155) was isolated from soil sample contaminated with spent engine-oil obtained from auto-mechanic workshops. One gram of soil sample was suspended in $10 \mathrm{ml}$ of sterile distilled water and a ten-fold dilution was carried out. $0.1 \mathrm{ml}$ of $10^{-2}$ dilution was inoculated onto the $\mathrm{m}$-cetrimide agar plate. The pure cultures obtained after subculture were maintained on nutrient agar slants at $4^{\circ} \mathrm{C}$.

This strain (CGA1) was selected based on high emulsification index, oil displacement, and drop collapse test results of its biosurfactant. It was identified by 16S ribosomal RNA sequencing. Genomic DNA extracted from the bacterial isolate was PCR amplified with the primer 27F (AGAGTTTGATCMTGGCTCAG) and 1492R (TACGGYTACCTTGTTACGACTT) using the DreamTaq Green PCR Master Mix (2X; ThermoFisher Scientific) under standard PCR conditions. Amplicons were purified and sequenced in two directions on an Applied Biosystems 3730XL 96-capillary DNA Sequencer. Raw sequence data (.ab1 format) were processed within the software package CLC genomics workbench (v11.0.1) to merge the forward and reverse reads. Merged and quality trimmed reads were analyzed using BLAST analysis and the software package MEGA7 [27].

The phylogenetic tree was constructed using the neighbor-joining tree. The minimum value of the nucleotide similitude percentage to define the species at the taxonomic level was $100 \%$. The $16 \mathrm{~S}$ rRNA gene sequence obtained from the isolate was compared with other bacterial sequences by using NCBI Mega BLAST. The nucleotide sequence was aligned in CLUSTALX. The phylogenetic analyses were performed using MEGA version 7 software [28].

\subsection{Fermentation Process and Preliminary Screening for Biosurfactant Production}

A submerged fermentation process was carried out following the method described in [29]. A mineral salt medium containing the following components was used: Basal medium (KCl, 1.1; $\mathrm{NaCl}, 1.1 ; \mathrm{FeSO}_{4} \cdot 7 \mathrm{H}_{2} \mathrm{O}, 0.00028 ; \mathrm{KH}_{2} \mathrm{PO}_{4}, 3.4$; $\mathrm{K}_{2} \mathrm{HPO}_{4}, 4.4 ; \mathrm{MgSO}_{4} \cdot 7 \mathrm{H}_{2} \mathrm{O}, 0.5$; Yeast extract, $0.5 \mathrm{~g} / \mathrm{L} ; 2 \mathrm{ml}$ of Trace element solution $\left[\mathrm{ZnSO}_{4} \cdot 7 \mathrm{H}_{2} \mathrm{O}, 0.29 ; \mathrm{CaCl}_{2} \cdot 4 \mathrm{H}_{2} \mathrm{O}, 0.24 ; \mathrm{CuSO}_{4} \cdot 5 \mathrm{H}_{2} \mathrm{O}, 0.25 ; \mathrm{MnSO}_{4} \cdot 7 \mathrm{H}_{2} \mathrm{O}\right.$, $0.17 \mathrm{~g} / \mathrm{L}]$ ); $\mathrm{NaNO}_{3}, 1.5 \mathrm{~g} / \mathrm{L}$ and Glucose, $2 \% \mathrm{w} / \mathrm{v}$ served as nitrogen and carbon sources respectively. The $\mathrm{pH}$ of the medium was adjusted to 7.2 with $1 \mathrm{~N} \mathrm{NaOH}$. A $50 \mathrm{ml}$ sterile medium in $100 \mathrm{ml}$ Erlenmeyer flask inoculated with $1 \mathrm{ml}$ of a standardized seed inoculum (using 0.5 Mcfarland standard) [30], was incubated for $72 \mathrm{~h}$ on an orbital shaker at $150 \mathrm{rpm}$ and $30^{\circ} \mathrm{C}$. Un-inoculated flask served as control. The cell-free supernatant obtained after two-time centrifugation at 4000 
$\mathrm{rev} / \mathrm{min}$ for 10 min was used for drop collapse test, oil displacement test, and emulsification index measurement.

\subsubsection{Drop Collapse Method of Screening}

A drop of the cell-free supernatant was placed on an oil-coated surface in a polystyrene microwell plate. Each well with a diameter of $8 \mathrm{~mm}$ and $0.03 \mathrm{~mm}$ depth was coated with $7 \mu \mathrm{l}$ mineral oil and left for $24 \mathrm{~h}$ at room temperature. A $20 \mu \mathrm{l}$ supernatant was then added to each well using a sterile syringe at an angle of $45^{\circ} \mathrm{C}$. Sterile distilled water was used as control. After one minute, the drops were examined visually for a positive or negative result. Drops containing biosurfactant collapsed whereas non-surfactant-containing drops remained stable [31].

\subsubsection{The Oil Displacement Technique}

The oil spreading technique measures the diameter of clear zones observed when a drop of a biosurfactant-containing solution is placed on an oil-water surface. A $40 \mathrm{ml}$ distilled water was placed in a large petri dish, followed by the addition of $15 \mu \mathrm{l}$ of crude oil to the surface of the water. The supernatant $(10 \mu \mathrm{l})$ was slightly placed on the surface of the oil film and allowed for $60 \mathrm{sec}$. The diameter of the clear zone on the oil surface was measured [32].

\subsubsection{Emulsification Index (E24)}

A mixture of $2 \mathrm{ml}$ of the supernatant and $2 \mathrm{ml}$ of kerosene was vortically stirred for $2 \mathrm{~min}$, and the height of the emulsion layer was measured after $24 \mathrm{~h}$, to determine the emulsification index. The emulsification index was calculated by measurement of the height of the emulsion layer (a), divided by the total height (b), and then multiplied by $100(E I=a / b \times 100)$ as described in [33].

\subsection{Optimization of Fermentation Conditions for Biosurfactant Production}

\subsubsection{Screening of Renewable Waste Materials as Sole Carbon Source and Assessment of Nitrogen Sources Using One Variable at a Time Method}

Five different waste materials (sugar cane molasses, spent lubricating motor oil, pulverized banana peel, pulverized potato peel, pulverized orange peel, and spent lubricating generator oil) were screened for use as a sole carbon source by $P$. aeruginosa strain CGA1 for the production of biosurfactant using one variable at a time method [34].

Different nitrogen sources $\left(\mathrm{KNO}_{3}, \mathrm{NH}_{4} \mathrm{Cl}, \mathrm{NaNO}_{3},\left(\mathrm{NH}_{4}\right)_{2} \mathrm{SO}_{4}\right)$ were also used in the fermentation medium one at a time for the evaluation of the most appropriate nitrogen source for the production of biosurfactant by $P$. aeruginosa strain CGA1.

Fermentation was carried out in a medium consisting of: Basal medium, nitrogen source, $1 \%(\mathrm{w} / \mathrm{v})$; carbon source, 2\% (w/v); pH, 7.2. A $100 \mathrm{ml}$ Erlenmeyer flask containing $50 \mathrm{ml}$ of the fermentation medium was inoculated with $1 \mathrm{ml}$ of 
the standardized seed inoculum and the flask incubated on an orbital shaker $(150 \mathrm{rpm})$ at $30^{\circ} \mathrm{C}$. Triplicate flasks were used and an uninoculated flask served as control. After $72 \mathrm{~h}$ fermentation, biosurfactant activity was determined by measuring the emulsification index (E24).

\subsubsection{Response Surface Method of Optimization}

A central composite design was used to optimize other critical media components. A $2^{4}$ full factorial central composite design (CCD) for four test variables, each at five levels with eight-star points and seven replicates at the center points was employed to fit a second-order polynomial model. The variables evaluated were concentration of sugar cane molasses $\left(\mathrm{X}_{1}\right)$ in the range between $5-25 \mathrm{~g} / \mathrm{L}$, the concentration of nitrogen $\left(\mathrm{X}_{2}\right)$ ranging from $5-25 \mathrm{~g} / \mathrm{L}$, inoculum size $\left(\mathrm{X}_{3}\right)$ in the range between $1-3 \mathrm{ml}$, and medium volume in $250 \mathrm{ml}$ flask $\left(\mathrm{X}_{4}\right)$ ranging from $20-60 \mathrm{ml}$. Minitab software version 17 was used to design the experiment. A total of 31 experiments were carried out, while the emulsification index was the measured experimental response.

\subsubsection{Experimental Validation of the Statistical Model}

The results obtained were further subjected to Analysis of Variance (ANOVA) to assess the significance of each variable on the biosurfactant production. The extent of variance that could be explained by the model was determined by the multiple regression coefficient $\left(R^{2}\right.$ value). The optimum conditions were validated and recorded as mean \pm standard deviation [26].

\subsection{Biosurfactant Extraction}

Pseudomonas aeruginosa strain CGA1 was cultured under the optimized conditions for $72 \mathrm{hr}$. Cells were removed by centrifugation at $4000 \mathrm{rev} / \mathrm{min}$ for 10 $\mathrm{min}$, and the supernatant was separated with a filter paper. The cell-free supernatant was acidified to $\mathrm{pH} 4.0$ using $6 \mathrm{M} \mathrm{HCl}$ and held overnight for precipitation. Then, a 1:1 volume of methanol-chloroform was added to the supernatant at room temperature to obtain crude extracts of the biosurfactant. The extracted biosurfactant was weighed after air drying on a pre-weighed Whatman filter paper.

\subsection{Surface Tension Measurement}

The surface tension of the cell-free culture broth was determined by capillary rise method [35]. The biosurfactant extract was added to $1 \mathrm{~L}$ of sterile distilled water in increasing concentration $(10-80 \mathrm{mg})$. A capillary tube $(0.01 \mathrm{~cm}$ diameter) was placed inside the solution. Surface tension was measured from the height of the water in the capillary tube using the equation: surface tension $(\gamma)=(\rho g a h) / 2$. Sodium dodecyl sulfate (SDS) was used as a control surfactant.

The Critical Micelle Concentration (CMC) was determined by plotting the surface tension as a function of the biosurfactant concentration. 


\subsection{Determination of Functional Components of the Biosurfactant Using Fourier Transform Infrared Spectroscopy (FT-IR) and Gas Chromatography-Mass Spectroscopy (GC-MS)}

\subsubsection{Fourier Transform Infrared Spectroscopy (FT-IR)}

The method described by [36] was used. A $2 \mathrm{mg}$ of the crude extracted biosurfactant was mixed with $200 \mathrm{mg} \mathrm{KBr}$ (Spectroscopic Grade) and the infrared spectra (with wavenumbers ranging from 4000 to $400 \mathrm{~cm}^{-1}$ ) were recorded in Shimadzu FT-IR-8400 spectrometer. The data collected were the average of 50 scans over the entire range.

\subsubsection{Gas Chromatography-Mass Spectroscopy (GC-MS)}

A $1 \mu \mathrm{l}$ of biosurfactant solution was injected into the Gas Chromatography-Mass Spectroscopy (GC-MS) machine: Agilent Technology 5890 gas chromatograph, with a split detector and Mass Spectrometer Detector (MSD). Helium was used as carrier gas at a constant flow of $1 \mathrm{ml} / \mathrm{min}$ and an injection volume of $1 \mu \mathrm{l}$, injector temperature $250^{\circ} \mathrm{C}$, and ion-source temperature $280^{\circ} \mathrm{C}$. Total GC running time was $90.67 \mathrm{~min}$ and the total length of time for running the analysis determined and programmed by the GC-MS analyst. Peaks in the chromatograms produced by these analyses were identified by a combination of references to their mass spectra and the NIST08 mass spectral database [37].

\subsection{Statistical Analysis}

Data obtained were subjected to one-way Analysis of Variance by Student-Newman-Keul (SNK) test at a 95\% confidence level. IBM SPSS statistics version 20 was used for the ANOVA.

\section{Results/Discussion}

\subsection{Isolation and Identification of the Biosurfactant-Producing Organism}

Pseudomonas aeruginosa strain CGA1 was isolated from spent-engine oil-polluted soil with ease using cetrimide agar as the isolation medium. Cetrimide agar is a medium for bacteria of the genus Pseudomonas because it contains cetrimide, which is the selective agent against other microbial flora [38]. The isolate was identified based on $16 \mathrm{~S}$ rRNA sequencing, and it showed $100 \%$ homology with other strains of Pseudomonas aeruginosa. The gene sequence was submitted to GenBank of NCBI with accession no. MT318155 and the phylogenetic tree of the isolate were constructed with the sequences of closely related microorganisms (Figure 1).

\subsection{Preliminary Screening for Biosurfactant Production}

The screening results showed that the isolate can efficiently produce biosurfactant under submerged culture conditions. It gave a strong positive drop collapse result, produced $1.8 \mathrm{~cm}$ diameter displacement on an oil film and high emulsification in$\operatorname{dex}(93.3 \%)$. 


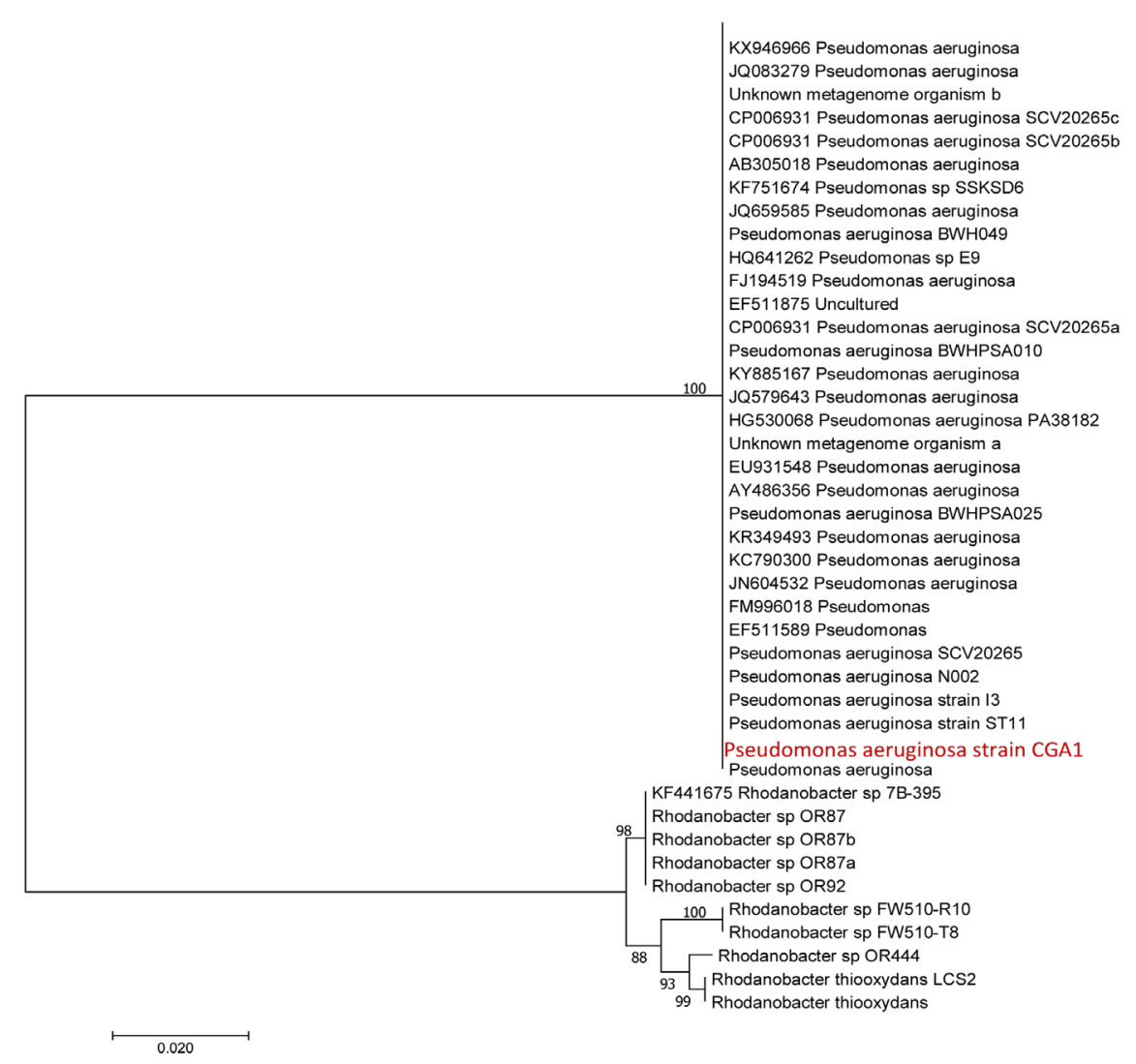

Figure 1. Evolutionary relationship of Pseudomonasaeruginosa strain CGA1 using the Neighbour-joining method.

\subsection{Optimization of Biosurfactant Production}

The selection of appropriate carbon and nitrogen sources or other nutrients is one of the most critical stages in the development of an efficient and economic biosurfactant production process [39]. Although most microorganisms produce biosurfactants in the presence of water-soluble substrates such as glucose, sucrose, glycerol, maltose, and other carbohydrates, the use of low-cost raw material as a carbon source is being emphasized on, to reduce production cost [40]. In line with one of the waste management strategies (reuse) and for cost-effective production of biosurfactant, several waste materials were screened for use as the carbon source for biosurfactant production by the $P$. aeruginosa strain CGA1 in this study. Biosurfactant yield was based on the emulsification index of the supernatant with a hydrophobic substrate (kerosene).

The various waste materials screened for use as a carbon source for biosurfactant production by CGA1 showed varying degrees of biosurfactant production (Figure 2). The biosurfactant yield with sugar cane molasses was significantly high $(77.6 \% \pm 2.6 \%)$ when compared to the other waste materials screened (p-value $<0.05$ ), while spent generator lubricating oil produced zero emulsification index. The high E24 observed with the use of sugar cane molasses in biosurfactant production may be attributed to sugar compositions (sucrose, fructose, glucose, and other carbohydrates) of the sugar cane molasses. This is in line with 


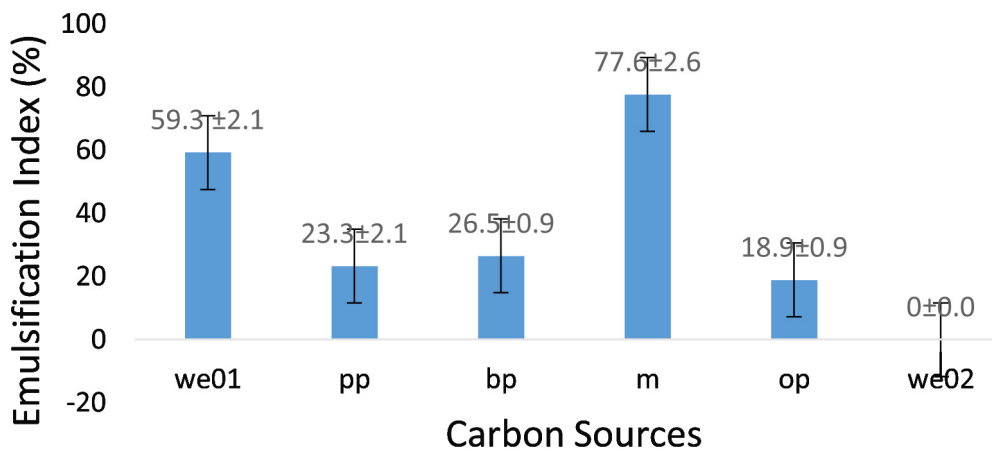

Figure 2. Screening of carbon sources for biosurfactant production. Key: weo1 is spent lubricating motor oil, pp is pulverized potato peel, bp is pulverized banana peel, $\mathrm{m}$ is sugar cane molasses, op is pulverized orange peel, while weo2 is spent lubricating generator oil.

Mouafo et al. [41], who reported an $81 \% \pm 1.14 \%$ emulsification index with sugar cane molasses as a carbon source for biosurfactant production by Lactobacillus strains. The use of molasses as a carbon source in fermentation medium increased rhamnolipid production by $P$. fluorescens [42].

On the screening of different nitrogen sources for biosurfactant production, sodium nitrate gave the highest biosurfactant yield $(88.3 \% \pm 1.5 \%)$ with CGA1 (Figure 3). The difference in biosurfactant yield by the various nitrogen sources evaluated was statistically significant ( $\mathrm{p}$-value $<0.05$ ).

Multiple regression analysis using response surface methodology was carried out to fit the regression model to the experimental data and investigate the effect of the four variables selected [43] Table 1, shows the central composite experimental design runs for optimization of biosurfactant production by the $P$. aeruginosa strain CGA1and the actual responses obtained. A total of 31 experiments were performed and emulsification indexes after were recorded as the response. The regression model, a quadratic polynomial equation, which gives the empirical interaction between the test variables and the response was obtained as

$$
\begin{aligned}
\mathrm{Y} 1(\mathrm{E} 24)= & 74.87+7.28 X_{1}+1.64 X_{2}-1.47 X_{3}+4.18 X_{4}-0.46 X_{1}^{2} \\
& +0.79 X_{2}^{2}-5.11 X_{3}^{2}-0.98 X_{4}^{2}-1.42 X_{1} X_{2}-0.07 X_{1} X_{3} \\
& +7.84 X_{1} X_{4}-1.57 X_{2} X_{3}-4.49 X_{2} X_{4}-1.49 X_{3} X_{4}
\end{aligned}
$$

where, $\mathrm{Y} 1$ is emulsification index, $X_{1}$ is the concentration of sugarcane molasses, $X_{2}$ is the concentration of sodium nitrate, $X_{3}$ is inoculum size and $X_{4}$ is medium volume.

\section{Experimental Validation of the Statistical Model}

Analysis of variance (ANOVA) which was used to test the significance and acceptability of the regression model obtained revealed that the regression model, linear and quadratic terms (squares), and interactions of the variables were statistically significant $(\mathrm{p}<0.05)$ (Table 2$)$. The non-significance of the lack of fit test indicated the adequacy of the model for optimum biosurfactant production by the isolate ( $\mathrm{p}$-value $>0.05)$ (Table 2$)$. 


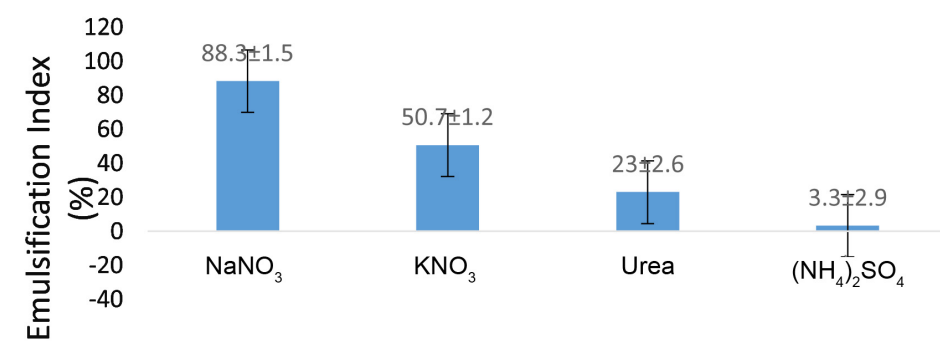

Nitrogen sources

Figure 3. Screening of nitrogen sources for biosurfactant production.

Table 1. Central composite design runs showing actual and coded variables and the responses.

\begin{tabular}{|c|c|c|c|c|c|}
\hline Run & $\begin{array}{c}\mathrm{X}_{1} \\
\text { Molasses (g/L) }\end{array}$ & $\begin{array}{c}\mathrm{X}_{2} \\
\text { Nitrate }(\mathrm{g} / \mathrm{L})\end{array}$ & $\begin{array}{c}\mathrm{X}_{3} \\
\text { Inoculum } \\
\text { size }(\mathrm{ml})\end{array}$ & $\begin{array}{c}\mathrm{X}_{4} \\
\text { Medium } \\
\text { volume }(\mathrm{ml})\end{array}$ & $\begin{array}{c}\text { Response (Y) } \\
\text { E24 }\end{array}$ \\
\hline 1 & $15(0)$ & $15(0)$ & $2(0)$ & $60(2)$ & 79.4 \\
\hline 2 & $10(-1)$ & $20(1)$ & $1.5(-1)$ & $50(1)$ & 58 \\
\hline 3 & $15(0)$ & $15(0)$ & $2(0)$ & $40(0)$ & 73.2 \\
\hline 4 & $10(-1)$ & $20(1)$ & $1.5(-1)$ & $30(-1)$ & 81.8 \\
\hline 5 & $20(1)$ & $10(-1)$ & $2.5(1)$ & $50(1)$ & 85.6 \\
\hline 6 & $20(1)$ & $20(1)$ & $1.5(-1)$ & $30(-1)$ & 69.3 \\
\hline 7 & $15(0)$ & $5(-2)$ & $2(0)$ & $40(0)$ & 80 \\
\hline 8 & $10(-1)$ & $20(1)$ & $1.5(-1)$ & $30(-1)$ & 73 \\
\hline 9 & $15(0)$ & $15(0)$ & $2(0)$ & $40(0)$ & 86.7 \\
\hline 10 & $20(1)$ & $10(-1)$ & $1.5(-1)$ & $50(1)$ & 88.3 \\
\hline 11 & $15(0)$ & $15(0)$ & $2(0)$ & $40(0)$ & 77 \\
\hline 12 & $15(0)$ & $25(2)$ & $2(0)$ & $40(0)$ & 78.8 \\
\hline 13 & $15(0)$ & $15(0)$ & $2(0)$ & $40(0)$ & 71 \\
\hline 14 & $15(0)$ & $15(0)$ & $1(-2)$ & $40(0)$ & 51 \\
\hline 15 & $10(-1)$ & $10(-1)$ & $2.5(1)$ & $50(1)$ & 55.3 \\
\hline 16 & $20(1)$ & $20(1)$ & $2.5(1)$ & $50(1)$ & 78.4 \\
\hline 17 & $15(0)$ & $15(0)$ & $2(0)$ & $40(0)$ & 73.2 \\
\hline 18 & $10(-1)$ & $10(-1)$ & $2.5(1)$ & $30(-1)$ & 55 \\
\hline 19 & $10(-1)$ & $10(-1)$ & $2.5(1)$ & $50(1)$ & 70 \\
\hline 20 & $25(2)$ & $15(0)$ & $2(0)$ & $40(0)$ & 93.8 \\
\hline 21 & $10(-1)$ & $20(1)$ & $2.5(1)$ & $50(1)$ & 52.8 \\
\hline 22 & $15(0)$ & $15(0)$ & $2(0)$ & $40(0)$ & 72 \\
\hline 23 & $20(1)$ & $20(1)$ & $2.5(1)$ & $30(-1)$ & 60 \\
\hline 24 & $20(1)$ & $10(-1)$ & $2.5(1)$ & $30(-1)$ & 60 \\
\hline 25 & $15(0)$ & $15(0)$ & $3(2)$ & $40(0)$ & 60 \\
\hline 26 & $10(-1)$ & $10(-1)$ & $1.5(-1)$ & $30(-1)$ & 53 \\
\hline 27 & $20(1)$ & $20(1)$ & $1.5(-1)$ & $50(1)$ & 95 \\
\hline 28 & $15(0)$ & $15(0)$ & $2(0)$ & $40(0)$ & 71 \\
\hline 29 & $5(-2)$ & $15(0)$ & $2(0)$ & $40(0)$ & 55 \\
\hline 30 & $15(0)$ & $15(0)$ & $2(0)$ & $20(-2)$ & 65.2 \\
\hline 31 & $20(1)$ & $10(-1)$ & $1.5(-1)$ & $20(-2)$ & 59.3 \\
\hline
\end{tabular}

Key: $\mathrm{CM}-$ Concentration of Molasses, $\mathrm{CN}-$ Concentration of sodium nitrate, IS-Inoculum size, $\mathrm{MV}-$ medium volume. 
Table 2. Analysis of variance (ANOVA) for the quadratic response surface model for biosurfactant production by Pseudomonas aeruginosa strain CGA1.

\begin{tabular}{cccccc}
\hline Source & DF & Adj SS & Adj MS & F-value & P-value \\
\hline Regression & 14 & 4027.31 & 287.66 & 6.07 & 0.000 \\
Linear & 4 & 1807.12 & 451.78 & 9.53 & 0.000 \\
Square & 4 & 807.49 & 201.87 & 4.26 & 0.016 \\
Interaction & 6 & 1412.70 & 235.45 & 4.97 & 0.005 \\
Error & 16 & 758.46 & 47.40 & & \\
Lack of fit & 10 & 570.21 & 57.02 & 1.82 & 0.240 \\
Pure error & 6 & 188.25 & 31.38 & & \\
Total & 30 & 4785.77 & & & \\
\hline
\end{tabular}

Key: $\mathrm{DF}=$ Degree of freedom, $\mathrm{SS}=$ Sum of squares, $\mathrm{MS}=$ Mean square, $\mathrm{P}$-value $\leq 0.05$ is significant at $95 \%$ Confidence level.

The fit of the model was determined by the regression coefficient $\left(\mathrm{R}^{2}\right)$ value, which was $84.15 \%$. This is indicative of adequate adjustment of the regression model to the experimental data, and that the model can explain $84.15 \%$ variability between the predicted and experimental data, thus proving the suitability of the model for the prediction of biosurfactant production by CGA1 under the experimental conditions [44]. The effect of the variables on biosurfactant production showed that only concentration of sugar cane molasses and medium volume had a significant effect on the biosurfactant production $(\mathrm{p}<0.05)$, indicating that the levels of the variables tested had a significant effect on the responses obtained (Table 3). Contour plots showing the interactive effects of the process variables on the response (E24) is presented in Figure 4. Only the concentration of sugarcane molasses, medium volume, and concentration of sodium nitrate, medium volume interactions had a significant effect on the production process (Figure 4(d) and Figure 4(e)). At varying levels of the variables, significant responses were obtained, however, the highest emulsification index was observed at regions away from the central value.

The optimization of the four variables for the best response (E24) in this study was carried out using the response optimizer of the Minitab software version 17. The optimum process condition prediction obtained by the regression model were coded as $2,-2,-0.1414,2$ for the concentration of sugarcane molasses, concentration of sodium nitrate, inoculum size and medium volume in $250 \mathrm{ml}$ conical flask respectively, which presents as $25 \mathrm{~g} / \mathrm{L}$ of sugarcane molasses, $5 \mathrm{~g} / \mathrm{L}$ of sodium nitrate, $1.93 \mathrm{ml}$ inoculum size and $60 \mathrm{ml}$ medium volume in $250 \mathrm{ml}$ conical flask. The concentration of biosurfactant extracted from the optimized fermentation medium was $7.52 \mathrm{~g} / \mathrm{L}$ with a 2.31 -fold increase in yield when compared to the un-optimized conditions $(3.26 \mathrm{~g} / \mathrm{L})$. To further validate the experimental model, the predicted optimum conditions were employed experimentally and the emulsification index obtained was $96.3 \% \pm 0.75 \%$ against the predicted emulsification index of $147 \%$. These results showed that the model is well fitted for optimum biosurfactant yield by CGA1. 
Table 3. Parameter estimates of the quadratic response surface model for biosurfactant production by Pseudomonas aeruginosa strain CGA1.

\begin{tabular}{cccccc}
\hline Model Term & Parameter Effect & Coefficient & SD & T-value & P-value \\
\hline Constant & & 74.87 & 2.60 & 28.77 & 0.000 \\
$\mathrm{X}_{1}$ & 7.275 & 3.638 & 0.703 & 5.18 & $0.000^{*}$ \\
$\mathrm{X}_{2}$ & 1.642 & 0.821 & 0.703 & 1.17 & 0.260 \\
$\mathrm{X}_{3}$ & -1.475 & -0.737 & 0.703 & -1.05 & 0.310 \\
$\mathrm{X}_{4}$ & 4.183 & 2.092 & 0.703 & 2.98 & $0.009^{*}$ \\
$\mathrm{X}_{1}{ }^{*} \mathrm{X}_{1}$ & -0.230 & -0.115 & 0.322 & -0.36 & 0.726 \\
$\mathrm{X}_{2}{ }^{*} \mathrm{X}_{2}$ & 0.395 & 0.198 & 0.322 & 0.322 & 0.548 \\
$\mathrm{X}_{3}{ }^{*} \mathrm{X}_{3}$ & -2.555 & -1.277 & 0.322 & -3.97 & $0.001^{*}$ \\
$\mathrm{X}_{4}{ }^{*} \mathrm{X}_{4}$ & -0.492 & -0.246 & 0.322 & -0.76 & 0.456 \\
$\mathrm{X}_{1}{ }^{*} \mathrm{X}_{2}$ & -0.712 & -0.356 & 0.430 & -0.83 & 0.420 \\
$\mathrm{X}_{1}{ }^{*} \mathrm{X}_{3}$ & -0.037 & -0.019 & 0.430 & -0.04 & 0.966 \\
$\mathrm{X}_{1}{ }^{*} \mathrm{X}_{4}$ & 3.919 & 1.959 & 0.430 & 4.55 & $0.000^{*}$ \\
$\mathrm{X}_{2}{ }^{*} \mathrm{X}_{3}$ & -0.787 & -0.394 & 0.430 & -0.92 & 0.374 \\
$\mathrm{X}_{2}{ }^{*} \mathrm{X}_{4}$ & -2.244 & -1.122 & 0.430 & -2.61 & $0.019^{*}$ \\
$\mathrm{X}_{3}{ }^{*} \mathrm{X}_{4}$ & -0.744 & -0.372 & 0.430 & -0.86 & 0.400 \\
\hline
\end{tabular}

p-value with superscript ${ }^{*}$ indicates significance at a $95 \%$ confidence interval.

\subsection{Surface Tension Measurement}

The capillary rise method used in this study was based on the fact that the height of the biosurfactant-containing liquid in a capillary tube is directly proportional to the surface tension of the liquid [35]. The biosurfactant thus reduces the surface tension (cohesive force between water molecules) and suppresses the height of the liquid in the tube. The biosurfactant produced by $P$. aeruginosa CGA1 was able to reduce the surface tension of water from 72.1 $\mathrm{mN} / \mathrm{m}$ to $35.0 \pm 0.0 \mathrm{mN} / \mathrm{m}$ against the control (SDS) which reduced surface tension of water to $33.3 \pm 0.3 \mathrm{mN} / \mathrm{m}$. Critical micelle concentration (CMC) was attained at $60 \mathrm{mg} / \mathrm{L}$ (Figure 5), and an increasing concentration of the biosurfactant above the CMC, no significant reduction in the surface tension was observed ( $\mathrm{p}$-value $>0.05$ ). Similarly, biosurfactant produced by Pseudomonas putida MTCC 2467 reduced surface tension of liquid from $74 \mathrm{mN} / \mathrm{m}$ to $35 \mathrm{mN} / \mathrm{m}$ [45]. However, a much lower surface tension reduction of 28.8 $\mathrm{mN} / \mathrm{m}$ was attained in distilled water by biosurfactant produced by Rhizopus arrhizus UCP1607 in low-cost culture medium [46].

\subsection{Determination of Functional Components of the Biosurfactant Using Fourier Transform Infrared Spectroscopy (FT-IR) and Gas Chromatography-Mass Spectroscopy (GC-MS)}

\subsubsection{Fourier Transform Infrared Spectroscopy (FT-IR)}

The FTIR identified the characteristic functional groups of the biosurfactant 


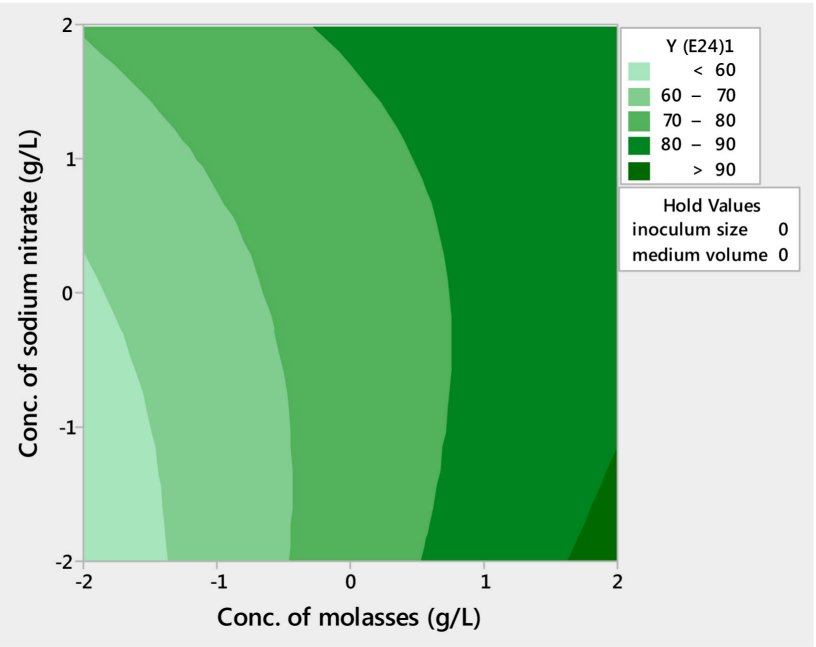

(a)

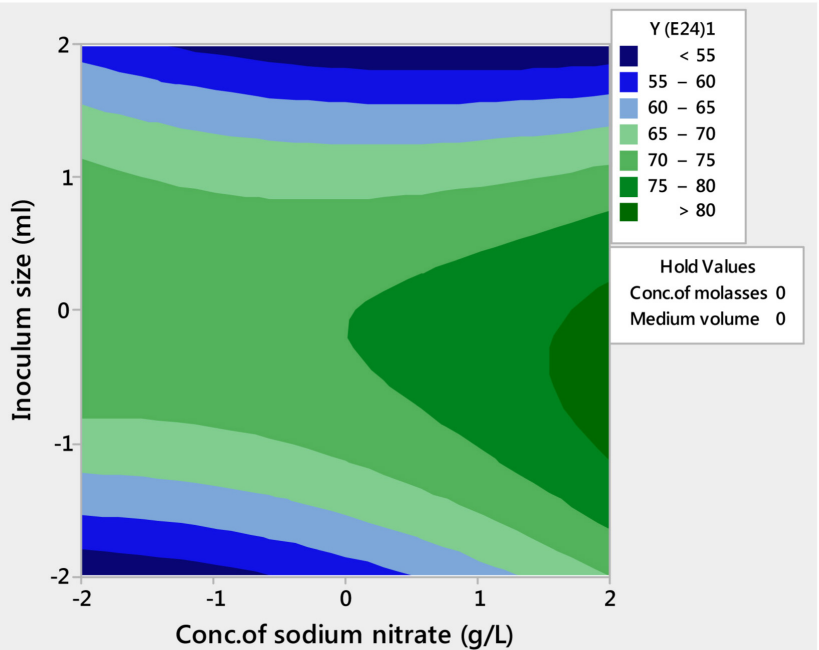

(c)

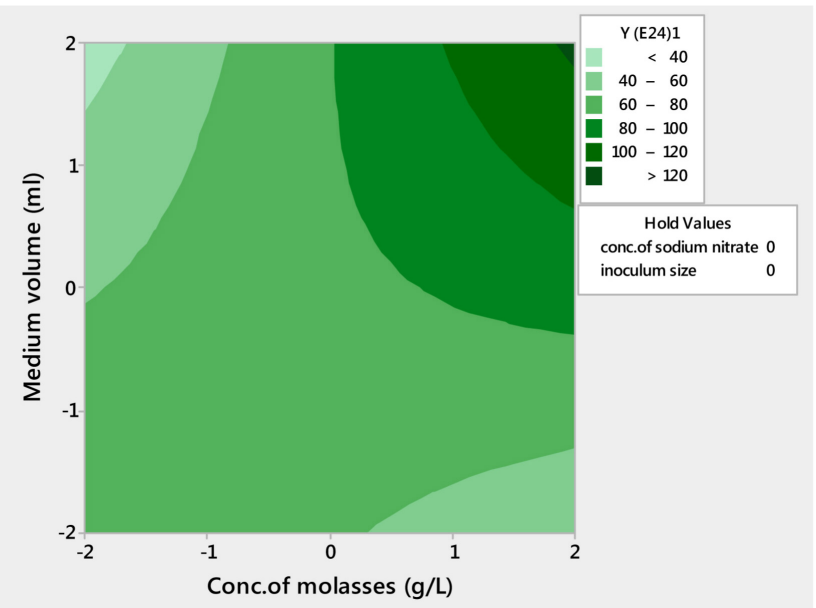

(e)

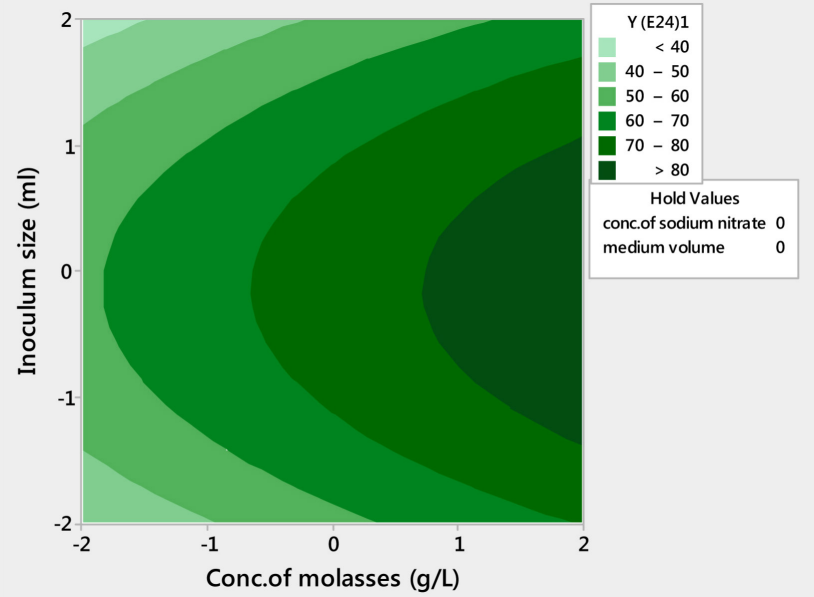

(b)

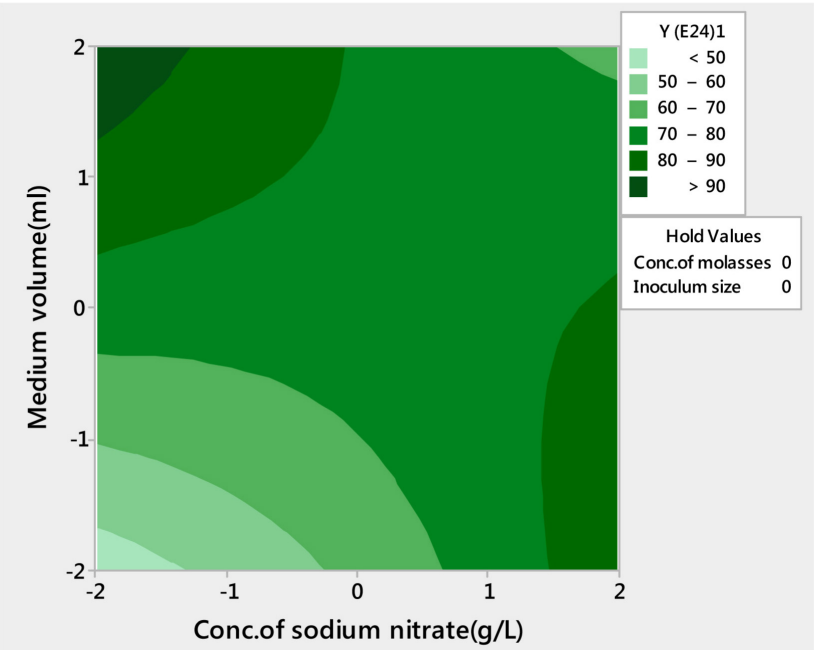

(d)

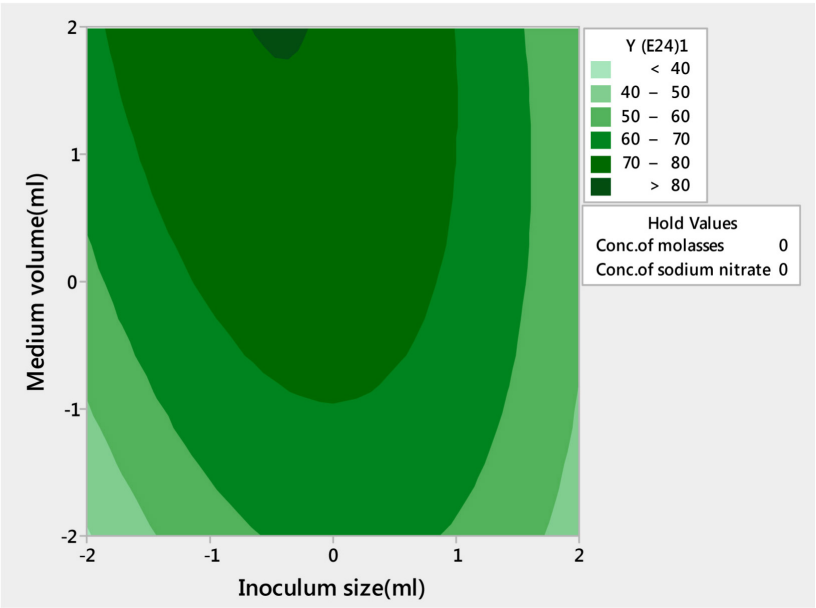

(f)

Figure 4. Response surface Contour plots showing the interactive effect of process variables on the emulsification index. (a) concentration of molasses and concentration of nitrate, (b) concentration of molasses and inoculum size, (c) concentration of molasses and medium volume, (d) concentration of nitrate and inoculum size, (e) concentration of nitrate and medium volume, (f) inoculum size and medium volume. 


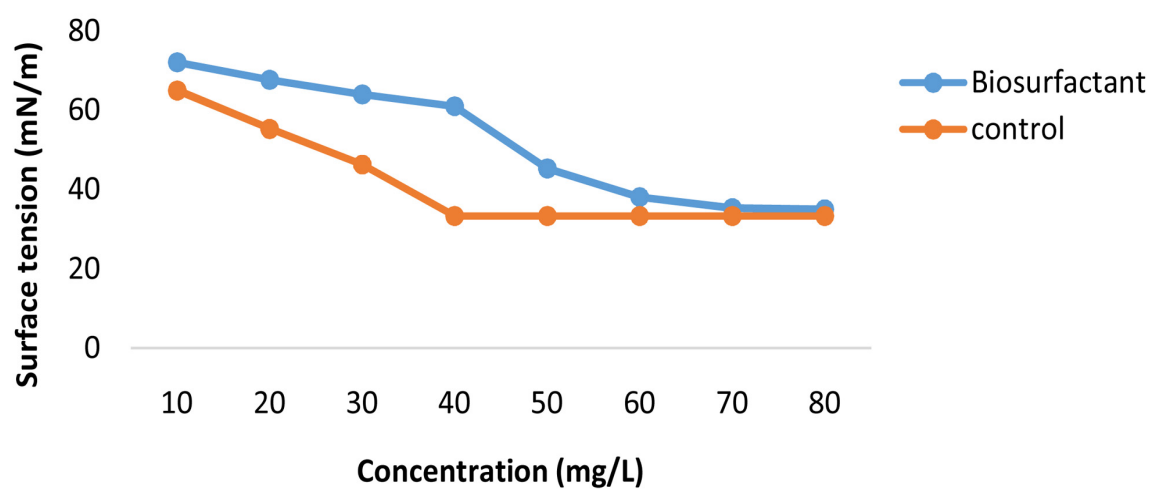

Figure 5. Surface tension measurement of the biosurfactant produced by $P$. aeruginosa strain CGA1.

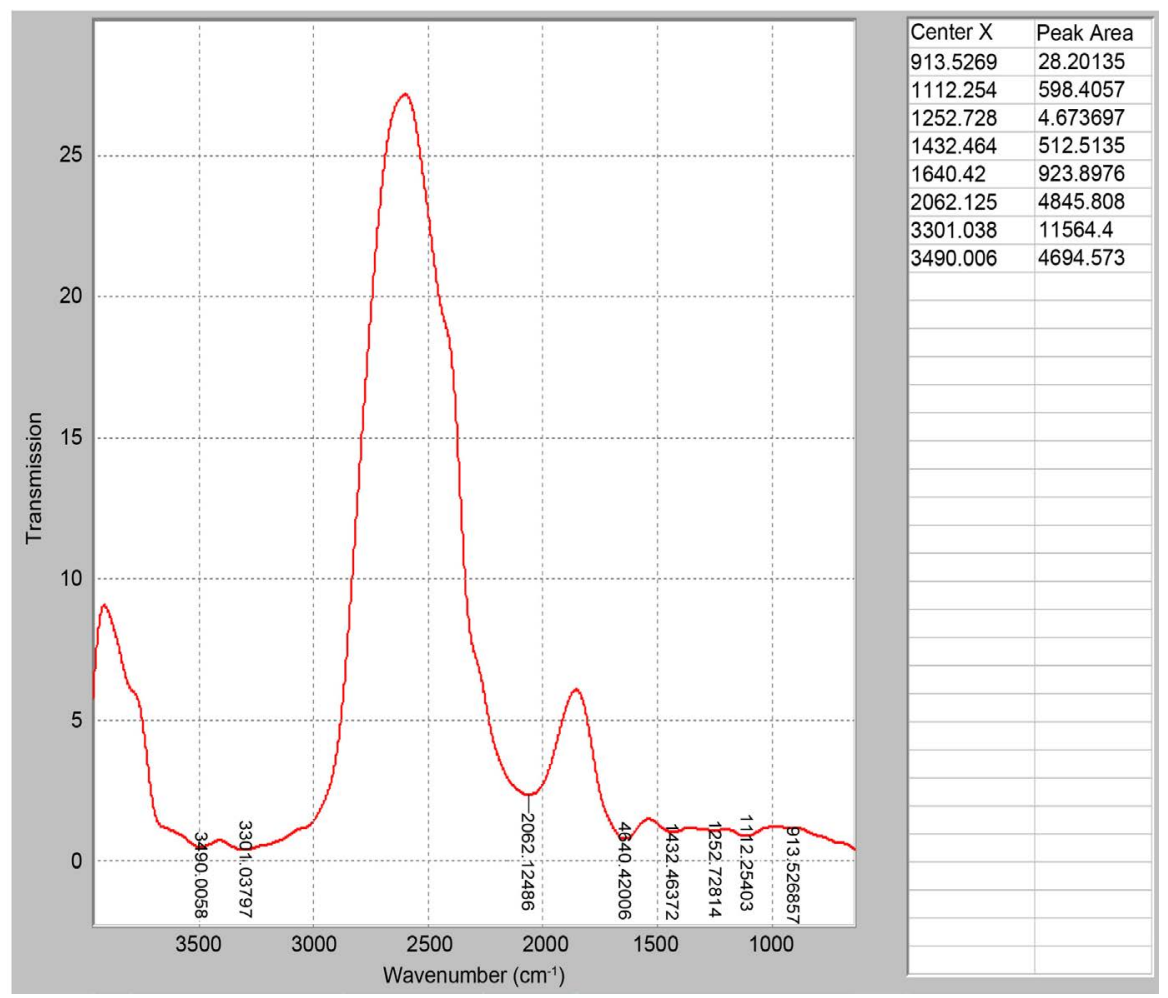

Figure 6. Transform infrared spectroscopy (FT-IR) spectrum of the biosurfactant.

Table 4. Functional components of the biosurfactants by GC-MS.

\begin{tabular}{cccc}
\hline Biosurfactant source & Functional component & Relative abundance (\%) & Formula \\
\hline $\begin{array}{c}\text { P. aeruginosa } \\
\text { strain CGA1 }\end{array}$ & Octadecanoic acid & 25.9 & $\mathrm{C}_{18} \mathrm{H}_{36} \mathrm{O}_{2}$ \\
& Methyl stearate & 7.79 & $\mathrm{C}_{19} \mathrm{H}_{38} \mathrm{O}_{2}$ \\
Cyclododecanol & 18.28 & $\mathrm{C}_{16} \mathrm{H}_{32} \mathrm{O}_{2}$ \\
& $\begin{array}{c}\text { Tert-Butyl isopropyl } \\
\text { disulphide } \\
\text { Cyclotetrasiloxane }\end{array}$ & 0.7 & $\mathrm{C}_{7} \mathrm{H}_{16} \mathrm{~S}_{2}$ \\
& & 0.73 & $\mathrm{C}_{8} \mathrm{H}_{24} \mathrm{O}_{4} \mathrm{Si}_{4}$ \\
\hline
\end{tabular}


Abundance

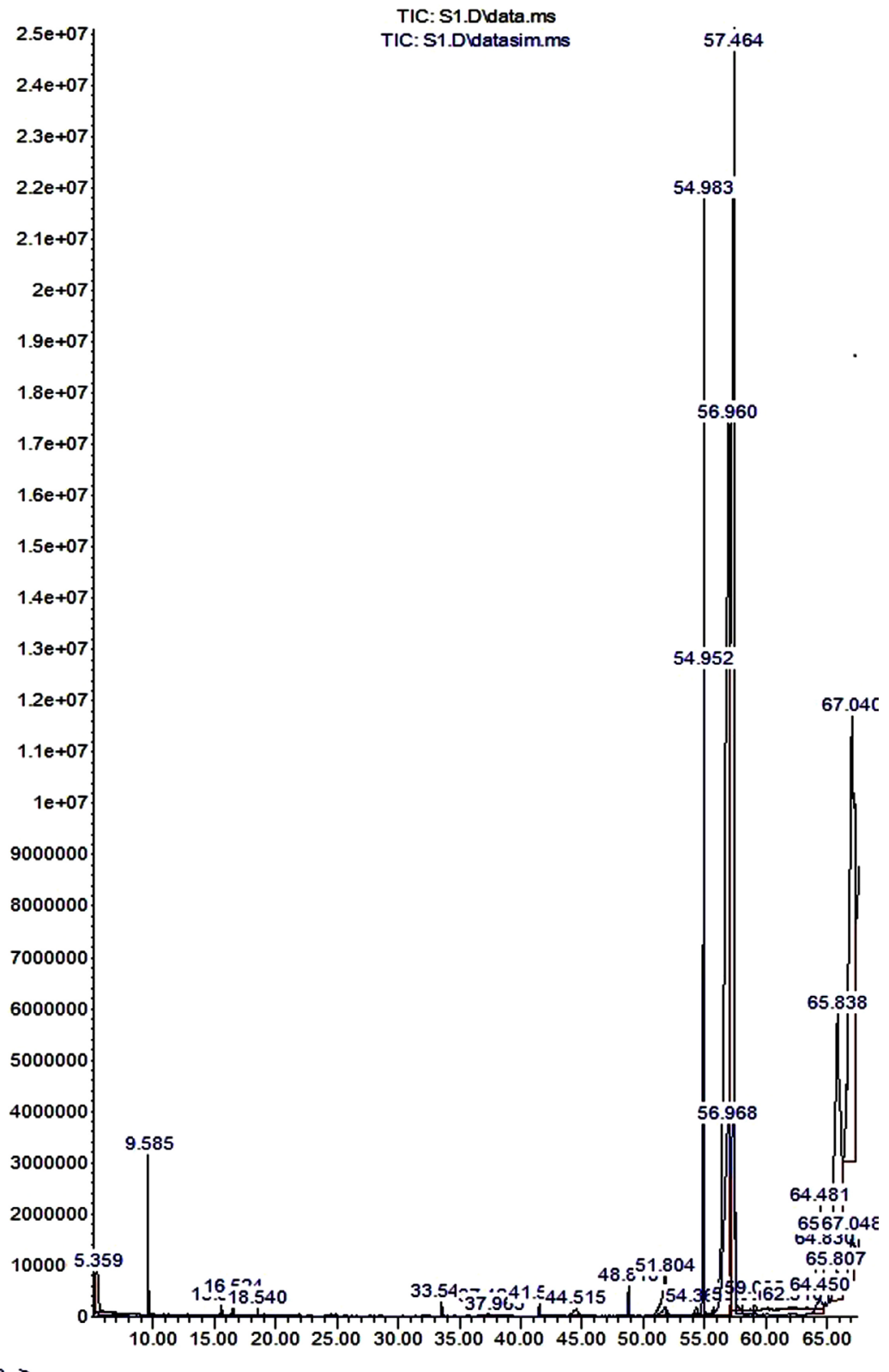

Figure 7. Mass spectrum from GC-MS analysis of the biosurfactant from $P$. aeruginosa CGA14.

produced (Figure 6). Characteristic peaks of peptides at $1640.420 \mathrm{~cm}^{-1}$ and $3490.006 \mathrm{~cm}^{-1}$ corresponding to $\mathrm{N}-\mathrm{H}$ stretching vibration of $1^{0}$ and $2^{0}$ amine compounds respectively, and $2063.125 \mathrm{~cm}^{-1}$ and $3301.038 \mathrm{~cm}^{-1}$ assigned to $\mathrm{C}=0$ and $0 \mathrm{H}$ stretching vibration of carboxylic acid and $1^{0}$ alcohol compounds were identified from the IR spectrum. The peaks at the fingerprint region with wavenumbers around $913.5269 \mathrm{~cm}^{-1}, 1112.254 \mathrm{~cm}^{-1}$ and $1252.726 \mathrm{~cm}^{-1}$ were assigned to $\mathrm{C} 0$ stretching vibration of ether compound, while peak value $1432.464 \mathrm{~cm}^{-1}$ represents $\mathrm{C}=\mathrm{C}$ stretching vibration of ethene compound. The 
FTIR spectrum implied that the biosurfactant produced by Pseudomonas aeruginosa strain CGA1 is a lipopeptide. Although, lipopeptide production is mostly associated with Bacillus species, for example, Bacillus aryabhattai [23], several Pseudomonas species have been identified as lipopeptide producers [47] [48] [49].

\subsubsection{Gas Chromatography-Mass Spectroscopy (GC-MS)}

The GC-MS analysis revealed the fatty acid components of the biosurfactant produced by CGA1 (Table 4). They include cyclotetrasiloxane, methyl stearate, octadecanoic acid, cyclododecanol, and tert-butyl isopropyl disulfide, with octadecanoic acid occurring most, having a relative abundance of 25.9\% (Figure 7). These components contribute to the tenso-active property of the produced biosurfactant. Octadecanoic acid commonly called stearic acid is a surface-active agent derived from natural fatty acids, which has excellent surfactant properties and is easily biodegraded [50]. Cyclotetrasiloxane is used as a hair conditioner, skin conditioner, and in other cosmetics as a foaming agent [51]. Recovery of these components as the functional components of the biosurfactant produced by Pseudomonas aeruginosa strain CGA1isin line with the reports of other researchers [52] [53] [54].

\section{Conclusion}

In the present study, results obtained showed that sugar cane molasses was efficient as the carbon source for biosurfactant production by Pseudomonas aeruginosa strain CGA1. Production was effectively optimized using response surface methodology and the produced biosurfactant was characterized as a lipopeptide that has high surface and interfacial tension reduction abilities.

\section{Conflicts of Interest}

The authors declare no conflicts of interest regarding the publication of this paper.

\section{References}

[1] Anaukwu, C.G., Ezemba, C.C., Anakwenze, V.N., Agu, K.C., Okeke, B.C., Awah, N.S. and Ekwealor, I.A. (2016) Effect of Biosurfactant Produced by Citrobacter murliniae AF025369 and a Synthetic Surfactant on Degradation of Crude Oil. Edorium Journal of Microbiology, 2, 1-6.

[2] Bertrand, B., Martínez-Morales, F., Rosas-Galván, N.S., Morales-Guzmán, D. and Trejo-Hernández, M.R. (2018) Statistical Design, a Powerful Tool for Optimizing Biosurfactant Production: A Review. Colloids and Interfaces, 2, 36-54. https://doi.org/10.3390/colloids2030036

[3] Mulligan, C.N., Sharma, S.K. and Mudhoo, A. (2014) Biosurfactants. In: Research Trends and Applications. CRC Press, Boca Raton, 34. https://doi.org/10.1201/b16383

[4] Hu, F.X., Liu, Y.Y. and Li, S. (2019) Rational Strain Improvement for Surfactin 
Production: Enhancing the Yield and Generating Novel Structures. Microbial Cell Factory 18, Article No. 42. https://doi.org/10.1186/s12934-019-1089-X

[5] Cheffi, M., Hentati, D. and Chebbi, A. (2020) Isolation and Characterization of a Newly Naphthalene-Degrading Halomonas pacifica, Strain Cnaph3: Biodegradation and Biosurfactant Production Studies. 3 Biotech, 10, Article No. 89. https://doi.org/10.1007/s13205-020-2085-X

[6] Mujumdar, S., Joshi, P. and Karve, N. (2019) Production, Characterization, and Applications of Bioemulsifiers (BE) and Biosurfactants (BS) Produced by Acinetobacter spp.: A Review. Journal of Basic Microbiology, 59, 277-287.

https://doi.org/10.1002/jobm.201800364

[7] Moshtagh, B., Hawboldt, K. and Zhang, B. (2019) Optimization of Biosurfactant Production by Bacillus subtilis N3-1P Using the Brewery Waste as the Carbon Source. Environmental Technology, 40, 3371-3380. https://doi.org/10.1080/09593330.2018.1473502

[8] El-Housseiny, G.S., Aboshanab, K.M., Aboulwafa, M.M. and Hassouna, N.A. (2019) RhamnolipidProduction by a Gamma Ray-Induced Pseudomonas aeruginosa $\mathrm{Mu}$ tant under Solid State Fermentation. Applied Microbiology and Biotechnology EXpress, 9, Article No. 7. https://doi.org/10.1186/s13568-018-0732-y

[9] Ribeiro, B.G., Guerra, J.M.C. and Sarubbo, L.A. (2020) Potential Food Application of a Biosurfactant Produced by Saccharomyces cerevisiae URM 6670. Frontiers in Bioengineering and Biotechnology, 8, 434.

https://doi.org/10.3389/fbioe.2020.00434

[10] Cristiane, B.L.R., Liziane, M.B.M., Caroline, B.B., Fabricio, B., Gustavo, U., Marcio, A.M. and Rodrigo, J.S. (2018) First Report of the Production of a Potent Biosurfactant with $\alpha, \beta$-Trehalose by Fusarium fujikuroi under Optimized Conditions of Submerged Fermentation. Brazilian Journal of Microbiology, 49, 185-192. https://doi.org/10.1016/j.bjm.2018.04.004

[11] Almeida, D.G., Soares da Silva, R.D.C.F., Luna, J.M., Rufino, R.D., Santos, V.A. and Sarubbo, L.A. (2017) Response Surface Methodology for Optimizing the Production of Biosurfactant by Candida Tropicalis on Industrial Waste Substrates. Frontiers in Microbiology, 8, 157.

[12] Sari, M., Kusharyoto, W. and Artika, I.M. (2014) Screening for Biosurfactant-Producing Yeast: Confirmation of Biosurfactant Production. Biotechnology, 13, 106-111. https://doi.org/10.3923/biotech.2014.106.111

[13] Adnan, M., Alshammari, E., Ashraf, S.A., Patel, K., Lad, K. and Patel, M. (2018) Physiological and Molecular Characterization of Biosurfactant Producing Endophytic Fungi Xylaria regalis from the Cones of Thuja plicata as a Potent Plant Growth Promoter with Its Potential Application. BioMed Research Internationa, 2018, Article ID: 7362148. https://doi.org/10.1155/2018/7362148

[14] Sharma, R., Singh, J. and Verma, N. (2018) Optimization of Rhamnolipid Production from Pseudomonas aeruginosa PBS towards Application for Microbial Enhanced Oil Recovery. 3 Biotech, 8, Article No. 20.

https://doi.org/10.1007/s13205-017-1022-0

[15] Charles, O.A., Julius, K.O., Mishra, P., Ravinder, S.J., Kumar, S.A., Singh, C.S. and Oluwasesan, M.B. (2017) Characterization and Optimization of a Rhamnolipid from Pseudomonas aeruginosa C1501 with Novel Biosurfactant Activities. Sustainable Chemistry and Pharmacy, 6, 26-36.

https://doi.org/10.1016/j.scp.2017.07.001 
[16] Rani, M., Weadge, J.T. and Jabaji, S. (2020) Isolation and Characterization of Biosurfactant-Producing Bacteria from Oil Well Batteries with Antimicrobial Activities against Food-Borne and Plant Pathogens. Frontiers in Microbiology, 11, 64.

[17] Smith, M.L., Gandolfi, S., Coshall, P.M. and Rahman, P.K.S.M. (2020) Biosurfactants: A Covid-19 Perspective. Frontiers in Microbiology, 11, 1341. https://doi.org/10.3389/fmicb.2020.01341

[18] Waghmode, S., Swami, S., Sarkar, D., Suryavanshi, M., Roachlani, S., Choudhari, P. and Satpute, S. (2020) Exploring the Pharmacological Potentials of Biosurfactant Derived from Planococcus maritimus SAMP MCC 3013. Current Microbiology, 77, 452-459. https://doi.org/10.1007/s00284-019-01850-1

[19] Kulkarni, P., Chakraborty, R. and Chakraborty, S. (2019) Biosurfactant Mediated Synthesis of Silver Nanoparticles Using Lactobacillus brevis (MTCC 4463) and Their Antimicrobial Studies. International Journal of Pharmaceutical Sciences and Research, 10, 1753-1759.

[20] Ohadi, M., Shahravan, A., Dehghannoudeh, N., Eslaminejad, T., Banat, I.M. and Dehghannoudeh, G. (2020) Potential Use of Microbial Surfactant in Microemulsion Drug Delivery System: A Systematic Review. Drug Design Development and Therapy, 14, 541-550. https://doi.org/10.2147/DDDT.S232325

[21] Banat, I.M., Satpute, S.K., Cameotra, S.S. and Nyayanit, N.V. (2014) Cost Effective Technologies and Renewable Substrates for Biosurfactants' Production. Frontiers in Microbiology, 5, 697. https://doi.org/10.3389/fmicb.2014.00697

[22] Ismail, W., Shammary, S.A., El-Sayed, W.S., Obuekwe, C., El Nayal, A.M., Raheem, A.S.A. and Al-Humam, A. (2015) Stimulation of Rhamnolipid Biosurfactants Production in Pseudomonasaeruginosa AK6U by Organosulfur Compounds Provided as Sulfur Sources. Biotechnology Report, 7, 55-63.

https://doi.org/10.1016/j.btre.2015.03.001

[23] Yaraguppi, D.A., Bagewadi, Z.K., Muddapur, U.M., and Mulla, S.I. (2020) Response Surface Methodology-Based Optimization of Biosurfactant Production from Isolated Bacillus aryabhattai Strain ZDY2. Journal of Petroleum Exploration Production Technology, 10, 2483-2498. https://doi.org/10.1007/s13202-020-00866-9

[24] Khuri, A.I. and Cornell, J.A. (1996) Response Surfaces: Design and Analyses. Marcel Dekker, New York.

[25] Joice, P.A. and Parthasarathi, R. (2014) Optimization of Biosurfactant Production from Pseudomonas aeruginosa PBSC1, International Journal of Current Microbiology and Applied Sciences, 3, 140-151.

[26] Onwosi, C.O. and Odibo, F.J.C. (2013) Use of Response Surface Design in the Optimization of Starter Cultures for Enhanced Rhamnolipid Production by Pseudomonas nitroreducens. African Journal of Biotechnology, 12, 2611-2617.

[27] Kumar, S., Stecher, G. and Tamura, K., (2016) MEGA7: Molecular Evolutionary Genetics Analysis Version 7.0 for Bigger Datasets. Molecular Biology and Evolution, 33, 1870-1874. https://doi.org/10.1093/molbev/msw054

[28] Tamura, K., Dudley, J., Nei, M. and Kumar, S. (2007) MEGA4: Molecular Evolutionary Genetics Analysis (MEGA) Software Version 4.0. Molecular Biology and Evolution, 24, 1596-1599. https://doi.org/10.1093/molbev/msm092

[29] Anaukwu, C.G., Ekwealor, A.I., Ezemba, C.C., Anakwenze, V.N., Okafor, U.C. and Archibong, E.J. (2015) Pseudomonas monteilii and Citrobacter murliniae, Biosur- 
factant-Producing Bacteria Isolated from Nigerian Soil. British Microbiology Research Journal, 10, 1-9. https://doi.org/10.9734/BMRJ/2015/19742

[30] Patel, J.B., Cockerill, F. R., Bradford, P.A., Eliopoulos, G.M., Hindler, J.A., Jenkins, S.G., Lewis, J.S., Limbago, B., Miller, L.A., Nicolau, D.P., Powell, M., Swenson, J.M., Traczewski, M.M., Turnidge, J.D., Weinstein, M.P. and Zimmer, B.L. (2015) Performance Standards for Antimicrobial Susceptibility Testing; Twenty-Fifth Informational Supplement (M100-S25). Clinical and Laboratory Standard Institute, Wayne, Pennsylvania, 132-135.

[31] Tugrul, S. and Cansunar, E. (2005) Detecting Surfactant-Producing Microorganisms by the Drop-Collapse Test. World Journal of Microbiology and Biotechnology, 21, 851-853. https://doi.org/10.1007/s11274-004-5958-y

[32] Morikawa, M., Daido, H., Takao, T., Murata, S. and Shimonishi, Y. (1993) A New Lipopeptide Biosurfactant Produced by Arthrobacter sp. Strain MIS38. Journal of Bacteriology, 175, 6459-6466. https://doi.org/10.1128/JB.175.20.6459-6466.1993

[33] Ellaiah, P., Prabhakar, T., Sreekanth, M., Taleb, A.T., Bhima, P. and Saisha, V. (2002) Production of Glycolipids Containing Biosurfactant by Pseudomonas Species. Indian Journal of Experimental Biology, 40, 1083-1086.

[34] Rane, A.N., Baikar, V.V., Ravi Kumar, V. and Deopurkar, R.L. (2017) Agro-Industrial Wastes for Production of Biosurfactant by Bacillus subtilis ANR 88 and Its Application in Synthesis of Silver and Gold Nanoparticles. Frontiers in Microbiology, 8, 492.

[35] Adamson, A.W. (1997) Surface Tension Measurement. In: Adamson, A.W. and Gast, A.P., Eds., Physical Chemistry of Surfaces. Wiley Publications, New York, 16-19. https://doi.org/10.3389/fmicb.2017.00492

[36] Hatef, Z.H. and Khudeir, S.H. (2017) Optimal Conditions for Naphthalene Biodegradation by Local Bacterial Isolates. International Journal of Science and Research, 6, 1790-1795. https://doi.org/10.21275/21121701

[37] Iowa State University (ISU) (2017) Agilent 5973 GCMS Training Manual. Chemical Instrumentation Facility, Iowa State University.

https://www.cif.iastate.edu/sites/default/files/uploads/MS/8453/5973\%20MSD\%20T raining\%20Guide2.pdf

[38] Elshafiee, E.A., Nader, S.M., Dorgham, S.M. and Hamza, D.A. (2019) Carbapenem-Resistant Pseudomonas aeruginosa Originating from Farm Animals and People in Egypt. Journal of Veterinary Research, 63, 333-337. https://doi.org/10.2478/jvetres-2019-0049

[39] Santos, D.K., Rufino, R.D., Luna, J.M., Santos, V.A. and Sarubbo, L.A. (2016) Biosurfactants: Multifunctional Biomolecules of the 21st Century. International Journal of Molecular Sciences, 17, 401. https://doi.org/10.3390/ijms17030401

[40] Nurfarahin, A.H., Mohamed, M.S. and Phang, L.Y. (2018) Culture Medium Development for Microbial-Derived Surfactants Production-An Overview. Molecules (Basel, Switzerland), 23, 1049. https://doi.org/10.3390/molecules23051049

[41] Mouafo, T.H., Mbawala, A. and Ndjouenkeu, R. (2018) Effect of Different Carbon Sources on Biosurfactants' Production by Three Strains of Lactobacillus spp. Hindawi BioMed Research International, 2018, Article ID: 5034783.

https://doi.org/10.1155/2018/5034783

[42] Suryanti, V., Marliyana, S.D. and Wulandari, A. (2015) Biosurfactant Production by Pseudomonas Fluorescens Growing on Molasses and Its Application in Phenol De- 
gradation. AIP Conference Proceedings, 1699, Article ID: 040003. https://doi.org/10.1063/1.4938318

[43] Aydar, A.Y. (2018) Utilization of Response Surface Methodology in Optimization of Extraction of Plant Material. In: Silva, V., Ed., Statistical Approaches with Emphasis on Design of Experiments Applied to Chemical Processes, IntechOpen Publishers, UK, 157-169.

[44] Kumar, A.P., Janardhan, A., Radha, S., Viswanath, B. and Narasimha, G. (2015) Statistical Approach to Optimize Production of Biosurfactant by Pseudomonas aeruginosa 2297. 3 Biotech, 5, 71-79. https://doi.org/10.1007/s13205-014-0203-3

[45] Kanna, R., Gummadi, S.N. and Kumar, G.S. (2014) Production and Characterization of Biosurfactant by Pseudomonas putida MTCC 2467. Journal of Biological Sciences, 14, 436-445. https://doi.org/10.3923/jbs.2014.436.445

[46] Pele, M.A., Ribeaux, D.R., Vieira, E.R., Souza, A.F., Luna, M.A.C., Rodríguez, D.M., Andrade, R.F.S., Alviano, D.S., Alviano, C.S., Barreto-Bergter, E., Santiago, A.L.C.M. and Campos-Takaki, G.M. (2019) Conversion of Renewable Substrates for Biosurfactant Production by Rhizopus arrhizus UCP 1607 and Enhancing the Removal of Diesel Oil from Marine Soil. Electronic Journal of Biotechnology, 38, 40-48. https://doi.org/10.1016/j.ejbt.2018.12.003

[47] Malviya, D., Sahu, P.K., Singh, U.B., Paul, S., Amrita Gupta, A., Gupta, A.R., Singh, S., Kumar, M., Paul, D., Rai, J.P., Harsh, V. Singh, H.V. and Brahmaprakash, G.P. (2020) Lesson from Ecotoxicity: Revisiting the Microbial Lipopeptides for the Management of Emerging Diseases for Crop Protection. International Journal of Environmental Research and Public Health, 17, 1434-1441. https://doi.org/10.3390/ijerph17041434

[48] Loiseau, C., Portier, E., Corre, M., Schlusselhuber, M., Depayras, S., Berjeaud, J. and Verdon, J. (2018) Highlighting the Potency of Biosurfactants Produced by Pseudomonas Strains as Anti-Legionella Agents. BioMed Research International, 2018, Article ID: 8194368. https://doi.org/10.1155/2018/8194368

[49] Thavasi, R., Nambaru, V.R.M., Jayalakshmi, S., Balasubramanian, T. and Banat, I.M. (2011) Biosurfactant Production by Pseudomonas aeruginosa from Renewable Resources. Indian Journal of Microbiology, 51, 30-36.

https://doi.org/10.1007/s12088-011-0076-7

[50] Klein, R., Muller, E., Kraus, B., Brunner, G., Estrine, B., Touraud, B., Heilmann, J., Kellermeier, M. and Kunz, W. (2013) Biodegradability and Cytotoxicity of Choline Soaps on Human Cell Lines: Effects of Chain Length and the Cation. Royal Society of Chemistry Advances, 3, 23347-23354. https://doi.org/10.1039/c3ra42812e

[51] Johnson, W., Bergfeld, W.F., Belsito, D.V., Hill, R.A., Klaassen, C.D., Liebler, D.C., Marks, J.G., Shank, R.C., Slaga, T.J., Snyder, P.W. and Andersen, F.A. (2011) Safety Assessment of Cyclomethicone, Cyclotetrasiloxane, Cyclopentasiloxane, Cyclohexasiloxane and Cycloheptasiloxane. International Journal of Toxicology, 30, 149-227. https://doi.org/10.1177/1091581811428184

[52] Parthipan, P., Preetham, E., Machuca, L.L., Rahman, P.K., Murugan, K. and Rajasekar, A. (2017) Biosurfactant and Degradative Enzymes Mediated Crude Oil Degradation by Bacterium Bacillus subtilis A1. Frontiers in Microbiology, 8, 193. https://doi.org/10.3389/fmicb.2017.00193

[53] Deepansh, S., Baljeet, S.S., Nikhil, C., Anshul, B. and Suresh, P. (2014) Production and Structural Characterization of Lactobacillus helveticus Derived Biosurfactant. 
The Scientific World Journal, 2014, Article ID: 493548.

https://doi.org/10.1155/2014/493548

[54] Lobna, M.A. and Ahmed, Z.A.A. (2013) Identification and Characterization of Biosurfactants Produced by Rhodococcus equi and Bacillus methylotropicus. Biological, Chemical and Environmental Science, 8, 341-358. 